\title{
First record of leucism for Carollia castanea Allen, 1890 (Phyllostomidae: Carollinae) in southeastern Costa Rica
}

David Josué Mejía-Quintanilla1, Diego Gómez-Hoyos², Rocío Seisdedos-de-Vergara², Bernal Rodríguez ${ }^{3} \&$ José $^{2}$ González-Maya²

1 Instituto de Conservación y Manejo de Vida Silvestre, Universidad Nacional, Heredia, Costa Rica.

2 Proyecto de Conservación de Aguas y Tierras, ProCAT Internacional / Fundación Sierra to Sea Costa Rica, Las Alturas, Coto Brus, Puntarenas, Costa Rica.

3 Escuela de Biología, Universidad de Costa Rica, San José, Costa Rica.

Correspondence

D. Gómez-Hoyos

E-mail: dgomez@procat-conservation.org

Received: 7 April 2017

Accepted: 15 September 2017

Published on-line: 3 October 2017

\section{Resumen}

Primer registro de leucismo para Carollia castanea Allen, 1890 (Phyllostomidae: Carollinae) en el sureste de Costa Rica

Carollia castanea se distribuye desde Honduras hasta Venezuela. Casos de leucismo no han sido reportados para esta especie pero si para otros filostómidos. Capturamos un adulto de C. castanea con leucismo en la Zona Protectora Las Tablas. Presentaba despigmentación en la punta de las alas, debajo del antebrazo y en la parte superior del uropatagio, pero las manchas blancas no cubrían una alta porción de la piel. Algunos casos de leucismo en murciélagos han sido explicados por endogamia en poblaciones pequeñas o aisladas, pero esto no está apoyado por evidencia empírica. Nuestro registro es anecdótico, y no podemos ofrecer una explicación ecológica o genética. Proponemos que los casos de leucismo sean evaluados en cada contexto específico y soportado por estudios poblacionales robustos.

Palabras clave: Coloración atípica, Murciélagos, Neotrópico, Talamanca.

\begin{abstract}
Carollia castanea is distributed from Honduras to Venezuela. Leucism has not been reported for this species but there are reports for other phyllostomid bats. An adult $C$. castanea with leucism was captured at Las Tablas Protected Zone, Costa Rica. It presented depigmentation on both wing tips, under the and on the upper part of the uropatagium, however the white patches did not cover a high proportion of its skin. Some leucism cases in bats have been explained by inbreeding in small or isolated population, but it is scarcely supported by empirical evidence. Our record is anecdotal therefore we cannot offer an ecological or even a genetic explanation. We propose that leucism cases should be assessed in each specific context where it is recorded, and supported by robust population studies.
\end{abstract}

Key words: Atypical coloration, Bats, Neotropics, Talamanca. 


\section{Introduction}

Melanin is the product of a biochemical synthetic pathway; its quantity and distribution is genetically controlled (Griffiths et al. 2000). Mutation on the genes involved in the synthesis of melanin can be manifested in chromatic disorders such as albinism or leucism (Griffiths et al. 2000, Zalapa et al. 2016). Leucism is a skin condition that results from total or partial lack of pigmentation on the skin or fur (van Grouw 2006).

Reports of leucism in terrestrial vertebrates are generally scarce but relatively common for bats (Arriaga-Flores et al. 2016). The high frequency of leucism in vertebrates has been explained by inbreeding (Hsu 2003), but the relationship between these genetic changes and their ecological consequences have been scarcely studied (Arriaga-Flores et al. 2016).

On bats, leucism is generally expressed with white patches on the skin and fur, and sometimes without white patches along with a paler complexion than normal skin color (Murariu \& Chisamera 2006). Cases of leucism in bats have been mainly reported as anecdotic observations of individuals, without a robust population study, therefore this chromatic disorder condition has not been related with genetic processes in the population level or are based on speculations (López-Wilchis \& Galvan 2012, Sánchez-Hernández et al. 2012, GarcíaMorales et al. 2013). Leucism reports in bats are increasing in the literature, with the most records in the family Phyllostomidae (Marín-Vásquez et al. 2010, Velandia-Perilla et al. 2013, Chacón et al. 2015, Zalapa et al. 2016).

Carollia Gray, 1838 includes five species in Central America (Reid 2009), four of which are reported for Costa Rica: Carollia perspicillata (Linnaeus, 1758), Carollia sowelli Baker, Solari \& Hoffmann, 2002, Carollia subrufa (Hahn, 1905) and Carollia castanea Allen, 1890 (Rodríguez-Herrera et al. 2014). C. castanea is distributed from western Honduras to Venezuela, Bolivia and western Brazil, mainly on the Caribbean slope from lowlands up to 1,100 MASL (Reid 2009). In Costa Rica, it is common in the lowlands, except on tropical dry forest, and is considered rare above 500 MASL (LaVal \& Rodríguez-Herrera 2002).

Leucism has been reported in C. brevicauda, C. perspicillata and C. sowelli. Even though $C$. castanea is a common species, there are currently are no reports of leucism for this species. Here we report the first case of leucism for $C$. castanea in Costa Rica and present a review of the reports of leucism in Latin America.

\section{Material and methods}

The specimen was collected at Las Alturas de Cotón Farm in the pacific slope of the Talamanca mountains, Costa Rica. This location is an important conservation area since it is part of Las Tablas Protected Zone, buffer area of La Amistad International Park. We conducted an occasional species inventory at the locality. We proctored training sessions to handle mist nets. Our objective was to train a student in handling nets and identifying bats to initiate inventorying of Chiroptera species in Las Tablas Protected Zone.

We conducted our survey at approximately 1,300 MASL, in a tributary stream of the Cotón river (8.93961, -82.82025 WGS84). We used a mist net $(6 \times 2 \mathrm{~m})$ placed over a stream that conveniently crossed a forest trail. We completed our survey at nights, from 19:00 to 22:00h between 26th and 28th -VII-2016. The individuals captured were identified using a taxonomic key for bats of Costa Rica (Timm et al. 1999).

\section{Results}

We accomplished a survey effort of 9 hours per net during which we found 8 bat species, all belonging to the family Phyllostomidae. Our records include Artibeus lituratus Olfers, 1818, Dermanura tolteca Saussure, 1860, Sturnira hondurensis Goodwin, 1940, Sturnira parvidens Goldman, 1917, Desmodus rotundus (É. Geoffroy, 1810), C. sowelli, C. perspicillata, and C. castanea. One of the three captured individuals of $C$. castanea exhibited the leucism condition.

The individual exhibiting leucism was found on the first night of our survey (26-VII-2016). We confirmed the individual as $C$. castanea by using the following morphometric characteristics: three colored stripes on its skin, $36.4 \mathrm{~mm}$ forearm and $15 \mathrm{~mm}$ tibia (Timm et al. 1999). The specimen is an adult male and it was housed in the Museo de Zoología of the Universidad de Costa Rica (catalogue number 4770 and collect permission No. SINAC-SE-CUS-PI-12-131-2016). The specimen 


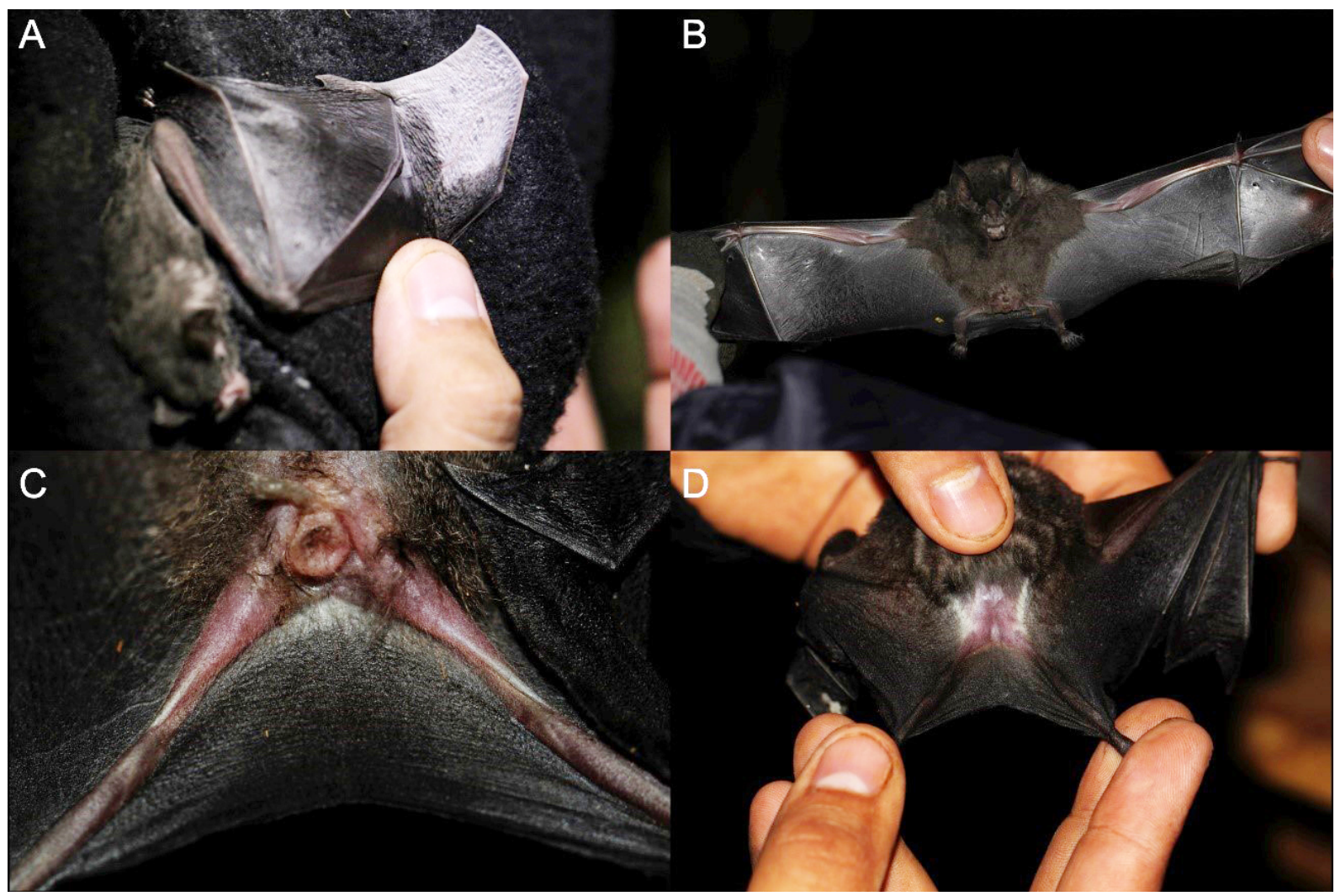

Figura 1. Individuo colectado de Carollia castanea con leucismo el 26-VII.2016 en la Zona Protectora Las Tablas, Costa Rica (número de catálogo 4770). A. Vista dorsal del ala izquierda con parches blancos; B. Vista ventral del cuerpo; C. Vista ventral del uropatagio; D. Vista dorsal con falta de pelaje sobre la parte baja del cuerpo.

Figure 1. Individual of Carollia castanea with leucism collected on 26-VII-2016 in Las Tablas Protected Zone, Costa Rica (catalogue number 4770). A. dorsal view of the left wing with white patches; B. ventral view of the body; C. ventral view of the uropatagium; D. dorsal view of the body with lack of fur on the lower area.

was preserved in fluid (fixed in formalin and stored in $70 \%$ alcohol). Leucism in the collected individual was exhibited in white-colored skin patches on both wing tips, axillar area and ventral area of the uropatagium (Fig. 1). We found no other skin color alterations on this individual, nonetheless it presented lack of fur on the inferior dorsal area of the body (Fig. 1D).

Currently, 27 species of Phyllostomidae have been reported with leucism in nine countries of Latin America (Soriano et al. 1993, Roncancio \& Ramírez 2008, Medina \& López 2010, MarínVásquez et al. 2010, Boada \& Tirira 2010, Acosta et al. 2011, Mantilla-Meluk \& Jiménez-Ortega 2011, Díaz \& Linares 2012, Marín-Vásquez et al. 2013, Velandia-Perilla et al. 2013, Tello et al. 2014, Chacón et al. 2015, Zalapa et al. 2016) and the cases potentially will continue to be registered, increasing reports in frequency and distribution, as well as in number of species. Records of leucism in Phyllostomidae have been increasing for the last years.

\section{Discussion}

Leucism condition is reported for Carollia brevicauda (Schinz, 1821) in Colombia and Venezuela (Soriano et al. 1993, Marín-Vásquez et al. 2010, Velandia-Perilla et al. 2013), C. perspicillata in Ecuador (Boada \& Tirira 2010), and $C$. sowelli in Mexico (Hernández-Mijangos 2009). To date, there are no records of leucism in Costa Rica for any Phyllostomidae, nor any records of leucism in C. castanea.

The most leucism records are represented in the family Phyllostomidae. However, geographic and taxonomic gaps still exist. We encourage researchers to fill these gaps with the publication of records from fieldwork studies and revision of museum specimens, such as the work by Velandia-Perilla et al. (2013). This way, we could understand the frequency, taxonomic representation, and geographic patterns of this atypical coloration. Also, it is necessary to understand the effects of this condition on behavior, reproduc- 
tion, and survival.

Leucism in bats is considered a rare condition in terms of frequency relative to survey efforts (e.g. Marín-Vásquez et al. 2010) or taxonomic representation (Gardner 2008). The explanation for low frequency and scarce taxonomic representation is the potential negative effects in reproduction and survival, such as reported for viperid snakes (Krecsák 2008) and otariids (Acevedo \& Aguayo 2008). However, recent records and discussion about atypical coloration in bats support that leucism condition does not have potential negative effects since its frequency is relative to survey effort (Velandia-Perilla et al. 2013), it is present in adults and pregnant females (GarcíaMorales et al. 2012; Velandia-Perilla et al. 2013), as well as has a wide taxonomic representation (Zalapa et al. 2016). However, the high frequency of leucism reported by Velandia-Perilla et al. (2013) was explained by the absence of predators in the island where the study was carried out.

It is considered that on small or isolated populations, leucism could be more frequent due to inbreeding (Hsu 2003, García-Morales et al. 2013). In some studies, leucism reports have been explained by inbreeding (e.g. López-Wilchis \& Galvan 2012, Sánchez-Hernández et al. 2012, García-Morales et al. 2013) but these studies are generally not based on robust population studies. However, our observation is anecdotal and therefore we cannot conclude about genetic processes involved or ecological consequences, in order to avoid these kind of speculations.

The individual we found was an adult and the white patches did not cover a high proportion of its skin. This suggests that the condition has not greatly affected its capacity to obtain food or avoid predation in contrast to other individuals with normal skin color. For this reason, we propose that any leucism effects in bats should be studied, with attention to different circumstances such as individual condition, taxonomic lineage, inter and intraspecific interaction, habitat, or spatial patterns. Thus, effects of leucism should not be generalized and this condition should be evaluated in each specific context where it is encountered.

\section{Acknowledgements}

We would like to thank Las Alturas de Cotón farm, ProCAT International, and Sierra to Sea Ins- titute Costa Rica for funding fieldwork. The authors thank Margarita López for her valuable comments and inputs, as well as Lauren Cruz for the English review, both of whom have improved our manuscript.

\section{References}

Acevedo J \& Aguayo M. 2008. Leucistic South American sea lion in Chile, with a review of anomalously color in otariids. Revista de Biología Marina y Oceanografía 32: 41-45

Acosta LH, Saldía M \& Nuñez LA. 2011. Historia natural del murciélago de hojas largas (Mironycteris microtis, Miller 1898), en la serranía de Incahuasi, San Cruz-Bolivia. Kempffiana 7: 19-33.

Arriaga-Flores JC, Rodríguez-Ruíz ER, Gallo-Reynoso JP \& Castro-Arellano I. 2016. Leucism in neotropical otters (Lontra longicaudis annectens) from Mexico. The Southwestern Naturalist 61(1): 63-68.

Boada C \& Tirira DG. 2010. First record of partial albinism (leucism) in Carollia perspicillata (Phyllostomidae) in Ecuador. Chiroptera neotropical 16(2): 755757.

Chacón PJJ, González Charrasquiel CM \& Ballesteros Correa J. 2015. Registro de leucismo en Artibeus planirostris (Chiroptera: Phyllostomidae) en Colombia. Acta Zoológica Mexicana 31(1): 125-128.

Diaz MM \& Linares VH. 2012. Refugio naturales y artificiales de Murciélagos (Mammalia: Chiroptera) en la selva baja en el noroeste de Perú. Guyana 76: 117130.

Gardner AL. 2008. Mammals of South America, Volume 1: Marsupial, xenarthran, shews, and bats. The University of Chicago and London, pp. 669.

García-Morales R, Tejada D, Ávila E, Moreno C \& Akmentins M. 2012. Registro de leucismo en Sturnira ludovici y Artibeus jamaicensis (Phyllostomidae) en México. Chiroptera Neotropical 18: 1101-1105

García-Morales R, Rojas-Martínez AE, Ávila Gómez ES \& Moreno CE. 2013. Leucism in the giant fruit-eating bat (Artibeus lituratus Olfers, 1818) in the state of Hidalgo, Mexico. Chiroptera Neotropical 19 (2): 1212-1215

Griffiths AJF, Miller JH, Suzuki DT, Lewontin RC \& Gelbart WM. 2000. An Introduction to Genetic Analysis. New York: WH Freeman.

Hernández-Mijangos LA. 2009. Registros de albinismo parcial en tres especies de murciélagos filostómidos (Chiroptera: Phyllostomidae) en Chiapas, México. Chiroptera Neotropical 15(1): 441-445.

Hsu MJ. 2003. Albinism in the Japanese house bat Pipistrellus abramus and the Formosan leaf-nosed bat Hipposideros terasensis in Taiwan. Mammalia 67(3): 451-453.

Krecsák L. 2008. Albinism and Leucism among European Viperinae: A review. Russian Journal of Herpetology 15(2): 97-102.

LaVal RK \& Rodríguez-Herrera B. 2002. Murciélagos de Costa Rica: Bats. Santo Domingo: INBio.

López-Wilchis R \& Galván AL. 2010. A noteworthy case 
of leucism in Artibeus lituratus (Chiroptera: Phyllostomidae) from Oaxaca, Mexico. Chiroptera Neotropical 18(1): 1111-1114.

Mantilla-Meluk H. \& Jiménez-Ortega A. 2011. First case of albinism in Uroderma bilobatum and its implications in the evolution of coat color patterns among Vampyressine bats. Investigación, Biodiversidad y Desarrollo 30: 97-100.

Marín-Vásquez A, Ortega-Rincón M \& Ramírez-Chaves HE. 2010. Records of leucism in three species of Colombian bats: Carollia brevicauda, Artibeus jamaicensis and Lophostoma silvicolum (Phyllostomidae). Chiroptera Neotropical 16(2): 706-709.

Marín-Vásquez A, González-lbarra I, Gualy L \& Díaz J. 2013. Aberrations in coat color pattern of colombian bats: isabelline, leucism and melanocytes nevus. Online Journal of BioSciences and Informatics 4(3): 253-265.

Medina C \& López E. 2010. Primer registro de leucismo en Sturnira lilium (Phyllostomidae) en el sureste del Perú. Chiroptera Neotropical 16(2): 758-761.

Murariu D \& Chisamera G. 2006. Partial albinism in noctule bat Nyctalus noctula (Schreiber, 1774) (Mammalia: Chiroptera) from Romania. Travaux du Muséum National d'Histoire Naturelle "Grigore Anitpa" 49: 353-357.

Reid FA. 2009. A field guide to the mammals of Central America \& Southeast Mexico. New York: Oxford University Press.

Rodríguez-Herrera B, Ramírez-Fernández JD, Villalobos-Chaves D \& Sánchez R. 2014. Actualización de la lista de especies de mamíferos de Costa Rica. Mastozoología Neotropical 21(1): 275-289.
Roncancio N \& Ramírez-Chaves HE. 2008. Registro de leucismo en Sturnira erythromos en los Andes centrales de Colombia. Chiroptera Neotropical 14: 412414.

Sánchez-Hernández C, Rojas-Martínez A, López-Vidal $\mathrm{JC}$, Elizalde-Arellano C, Romero-Almaraz ML, Aguilar-López M \& Taboada-Salgado A. 2012. Leucism in five species of bats from Mexico. Chiroptera Neotropical 18: 1123-1127.

Soriano P, Utrera A \& Sosa M. 1993. Dos registros de murciélagos albinos para Venezuela. Biollania 9: 149-150.

Tello C, Streicker DG, Gomez J \& Velazco PM. 2014. New records of pigmentation disorders in molossid and phyllostomid (Chiroptera) bats from Peru. Mammalia 78(2): 191-197.

Timm RM, LaVal RK \& Rodríguez B. 1999. Clave de campo para los murciélagos de Costa Rica. Brenesia 52: 1-32.

van Grouw H. 2006. Not every White bird is an albino: sense and nonsense about color aberrations in birds. Dutch Birding 28: 79-89

Velandia-Perilla JH, Yusti-Muñoz AP, Sánchez-Martínez MA \& Giraldo A. 2013. Leucism in leaf nosed bats (Chiropterae: Phyllostomidae) of Colombia. Boletín Científico Centro de Museos, Museo de Historia Natural 17(2): 87-94.

Zalapa SS, Guerrero S, Romero-Almaraz ML \& Sánchez-Hernández C. 2016. Coloración atípica en murciélagos: frecuencia y fenotipos en Norte y Centroamérica e islas del Caribe y nuevos casos para México y Costa Rica. Revista Mexicana de Biodiversidad 87: 474-482. 